УДК 331.108.43:06.08

DOI https://doi.org/10.26661/2310-4368/2021-2-12

\title{
ЗАДОВОЛЕНІСТЬ ПРАЦЕЮ В КОНТЕКСТІ ПРОФЕСІЙНОЇ САМОРЕАЛІЗАЦІЇ ПЕРСОНАЛУ: РЕЗУЛЬТАТИ ЕМПІРИЧНОГО ДОСЛІДЖЕННЯ
}

\author{
Ткалич М. Г. \\ доктор психологічних наук, дочент, \\ професор кафедри психології \\ Інститут підготовки кадрів Державної служби зайнятості України \\ вул. Нововокзальна, 17, Київ, Украӥна \\ orcid.org/0000-0003-4101-9659 \\ mtkalych@gmail.com \\ Дубяга Я. I. \\ доктор філософії з психологї, \\ провідний фахівець з профорієнтаиіі \\ Оріхівська районна філія \\ Запорізького обласного ичентру зайнятості \\ вул. Покровська, 37-а, Оріхів, Запорізька область, Украӥна \\ orcid.org/0000-0001-8046-3811 \\ yana020881@gmail.com
}

\begin{abstract}
Ключові слова: самореалізація особистості, професійна самореалізачія, рефлексивнорезультативний компонент самореалізації, задоволеність професійною діяльністю, державна служба зайнятості, фахівецьь.
\end{abstract}

Стаття присвячена аналізу результатів емпіричного етапу дослідження особливостей самореалізації фахівців державної служби зайнятості (ДСЗ) - задоволеності професійною діяльністю як рефлексивнорезультативного компоненту цього процесу. Визначено теоретичне підгрунтя дослідження та основні особливості професійної самореалізації особистості, яка $€$ індивідуальним, циклічним, динамічним та безупинним процесом реалізації особистісного потенціалу, відображає всі етапи професійного розвитку особистості, що характеризуються підвищенням професійного рівня, у процесі якої відбувається формування образу «Я-професіонал», розвиток професійної ідентичності, професійної зрілості. Виокремлено специфікусамореалізаціїфахівцівслужбизайнятості,якувизначаютьдекілька основних iї компонентів: особистісний, професійно-компетентнісний та рефлексивно-результативний компоненти, які узгоджуються 3 концепціями професійного розвитку особистості та особливостями професійної діяльності фахівців ДСЗ. Визначено місце задоволеності професійною діяльністю в контексті самореалізації. Критеріями задоволеності професійною діяльністю виступають соціально-психологічні та організаційні, соціальноекономічні складові діяльності фахівців Служби. Емпіричним шляхом доведено, що рівень задоволеності професійною діяльність фахівців ДСЗ $є$ середнім. Найбільше фахівці ДС3 $(n=318)$ задоволені взаємовідносинами 3 колегами та умовами праці, проте проблемними є параметри професійної відповідальності, професійного статусу та змісту роботи порівняно із заробітком. Виявлені особливості задоволеності працею у фахівців за статтю, віком, стажем роботи в ДСЗ та специфікою професійної діяльності. Основні відмінності стосуються вікових груп фахівців, а, отже, рівнів особистісної зрілості (з якою пов'язана професійна відповідальність), стажу роботи. Результати дослідження засвідчили наявність ряду проблем у рівні задоволеності професійною діяльністю фахівців служби зайнятості, що вказують на необхідність впровадження та застосування технологій розвитку їx професійної самореалізації загалом та підвищення рівня задоволеності професійною діяльністю зокрема. 


\title{
JOB SATISFACTION IN THE CONTEXT OF PROFESSIONAL SELF-REALIZATION OF PERSONNEL: THE RESULTS OF EMPIRICAL RESEARCH
}

\author{
Tkalych M. H. \\ Doctor of Psychological Sciences, Associate Professor, \\ Professor at the Department of Psychology \\ Ukrainian State Employment Service Training Institute, \\ Novovokzalna str., 17, Kyiv, Ukraine \\ orcid.org/0000-0003-4101-9659 \\ mtkalych@gmail.com \\ Dubiaha Ya. I. \\ PhD in Psychology, \\ Leading Vocational Guidance Specialist \\ Orikhiv District Branch of Zaporizhia Regional Employment Center \\ Pokrovska str., 37-a, Orikhiv, Zaporizhzhia region, Ukraine \\ orcid.org/0000-0001-8046-3811 \\ yana020881@gmail.com
}

Key words: self-realization of personality, professional selfrealization, reflexive-productive component of self-realization, job satisfaction, state employment service, specialist.
The article is devoted to the analysis of the empirical study results of the peculiarities of self-realization of specialists of the state employment service (PES) - satisfaction with professional activity as a reflexive and effective component of this process. It has been determined the theoretical basis of the study and the main features of professional self-realization of the individual, which is an individual, cyclical, dynamic and continuous process of personal potential, reflects all stages of professional development, characterized by improving the professional level, in the process of forming the image of "Selfprofessional", development of professional identity, professional maturity. The study highlighted the specifics of self-realization of employment service professionals, which is determined by several main components: personal, professional-competence and reflexive-productive components, which are consistent with the concepts of professional development and the professional activities of SES specialists. The place of satisfaction with professional activity in the context of self-realization has been also determined. The criteria of satisfaction with professional activity are socio-psychological and organizational, socio-economic components of the Service. It has been empirically proven that the level of satisfaction with the professional activity of SES specialists is average. Most PES specialists $(n=318)$ are satisfied with the relationship with colleagues and working conditions, but the parameters of professional responsibility, professional status and content of work compared to earnings are problematic. Determination of job satisfaction of specialists by sex, age, length of service in the SES and the specifics of professional activity were revealed. The main differences concern the age groups of specialists, and, consequently, the levels of personal maturity (which is associated with professional responsibility), work experience. The results of the study has showed a number of problems in the level of job satisfaction of employment service professionals, indicating the need to introduce and apply technologies for the development of their professional self-realization in general and increase satisfaction with professional activity in particular. 
Постановка проблеми. Професійна діяльність не просто засіб забезпечити собі життя, а особливий циклічний та динамічний процес, який змінює і розвиває особистість, забезпечує її здійснення як реального суб'єкта діяльності, що відтворює в ній свій соціальний світ. Спонукання до професійної самореалізації у людини виникає у зв'язку з незадоволеною потребою в реалізації своїх професійних вмінь та здібностей (професійного потенціалу), бажанням належати до певної професійної спільноти (потреба у професійній ідентичності), отримувати задоволення від результатів діяльності (користь суспільству, самоповага), досягати поставлених цілей. На нашу думку, потреба в самоактуалізації $\epsilon$ фундаментальною складовою зрілої особистості, яка сприяє формуванню її професійної зрілості.

Професійна самореалізація є складним феноменом, який містить багато компонентів та обумовлений низкою чинників. Ми розглядаємо задоволеність професійною діяльністю як рефлексивно результативний компонент професійної самореалізації особистості [11], який є важливим для суб'єктивної оцінки самореалізації фахівцем.

Мета статті: проаналізувати результати емпіричного етапу дослідження особливостей самореалізації фахівців державної служби зайнятості (ДСЗ) - задоволеності професійною діяльністю як рефлексивно-результативного компоненту цього процесу.

Аналіз останніх досліджень i публікацій. Проблема самореалізації та самоактуалізації у професійній діяльності $\epsilon$ предметом наукових розробок вже понад 20 років. Сучасні концепції особистісно-професійного розвитку представлені у працях Л. Карамушки, О. Кокуна, Л. Коростильової, Д. Леонтьєва, П. Лушина, С. Максименка, О. Огієнко, Л. Сердюк, Т. Титаренко, М. Ткалич, та ін.; положення щодо професійних компетенцій та компетентностей фахівців - у працях Н. Бібік, Ю. Борець, Ж. Вірної, І. Матійків, А. Мудрик, О. Овчарук, та ін.; дослідження особливостей професійної діяльності та кар'єрного зростання фахівців ДС3 у дослідженнях Є. Калюжної, О. Ковбаско, Л. Ляміної, Ю. Маршавіна, Л. Матвієнко, Н. Ортікової, О. Смирнової, та ін. Безпосередньо задоволеність професійної діяльністю розробляються Б. Генкіним, Л. Малімон, Л. Мітіною, С.Г. Москвичовим, М. Ткалич, та ін.

Представлені наукові розробки були нами враховані при побудові моделі самореалізації фахівців державної служби зайнятості та визначили спрямованість емпіричного вивчення проблеми.

Виклад основного матеріалу дослідження. Потреба у професійній самореалізації $є$ комплексним поняттям і складається з багатьох компонентів: усвідомлення професійних здібностей, професійно-ціннісні орієнтації, професійне цілепокладання, рівень домагань особистості, професійна зрілість та професійна ідентичність $[1 ; 3 ; 5]$.

На основі теоретичного аналізу проблеми, можна говорити про такі особливості професійної самореалізації особистості:

1. Професійна самореалізація є індивідуальним, циклічним, динамічним та безупинним процесом реалізації особистісного потенціалу людини в професійній діяльності.

2. Професійна самореалізація відображає всі етапи професійного розвитку особистості, що характеризуються підвищенням професійного рівня особистості.

3. В процесі професійної самореалізації відбувається формування образу «Я-професіонал», розвиток професійної ідентичності, професійної зрілості.

В контексті аналізу професійної діяльності фахівців ДСЗ [4; 6; 7; 8; 9; 11], виокремимо такі іiі особливості: клієнтоорієнтованість, що передбачає індивідуальних підхід до кожного клієнта, кожної конкретної ситуації безробіття; інтенсивні контакти з клієнтами різного віку, статі, освітнього рівня, професійного досвіду; підвищена емоційна та психологічна напруженість при роботі 3 клієнтами, що знаходяться в різних емоційних станах; широкий діапазон складності посадових обов'язків, що вимагає високого рівня професійної компетентності; інноваційність, динамічність та творчий характер праці, що проявляється у постійному вдосконаленні методів роботи, ефективному використанню ресурсів, пошуку нових можливостей; висока моральна та професійна відповідальність перед клієнтами, колегами, безпосереднім керівництвом та суспільством; необхідність безперервного підвищення особистісного та професійного рівня.

Особливості професійної самореалізації в професійній діяльності фахівців ДСЗ визначають декілька основних iï компонентів: особистісний, професійно-компетентнісний та рефлексивно-результативний компоненти, які, на наш погляд, в повній мірі узгоджуються з концепціями професійного розвитку особистості та особливостями професійної діяльності фахівців ДСЗ.

Одним 3 показників рефлексивно-результативного компоненту самореалізації ми визначаємо задоволеність професійною діяльністю фахівцями.

Л. Карамушка та М. Ткалич зазначають, що задоволеність професійною діяльністю розуміється як ставлення до праці в найбільш загальному плані; усвідомлення робочих можливостей насичення своїх потреб, значущості своєї праці, ролі, результатів професійної діяльності сьогодні або в майбутньому [2]. 
На наш погляд, задоволеність професійною діяльністю визначається як усвідомлення праці, ролі, результатів професійної діяльності сьогодні або в майбутньому. Таким чином, йдеться про свідоме, когнітивне ставлення особистості до реалізації своїх потреб у праці.

Критеріями задоволеності професійною діяльністю, на наш погляд, $є$ наступні:

1) соціально-психологічні: можливості професійного росту, кар'єри, престижність професійної діяльності, ставлення до професійної діяльності рідних друзів, соціально-психологічний клімат у колективі тощо.

2) організаційні, соціально-економічні: матеріальна винагорода, наявність достатньої кількості вільного часу, організація робочого місця, графік роботи, соціальні гарантії тощо.

На підставі вищезазначеного, до складу загальної задоволеності професійною діяльністю фахівця служби зайнятості нами віднесено: інтерес до роботи, задоволеність змістом роботи, задоволеність досягненнями у роботі, задоволеність взаємовідносинами з колегами та керівництвом, задоволеність професійним статусом, задоволеність умовами праці.

3 урахуванням теоретичних узагальнень було проведено емпіричне вивчення особливостей задоволеності працею фахівців ДСЗ. Дослідження проводилося у Запорізькій, Дніпропетровській, Львівській та Одеській областях. В опитуванні взяли участь 318 фахівців державної служби зайнятості.

Для визначення рівня задоволеності працею фахівців ДСЗ була використана методика «Інтегральна задоволеність працею», яка визначає задоволеність працею в цілому та окремо по кожній шкалі. Шкала «Інтерес до роботи» відображає зацікавленість змістом та процесом діяльності. Шкала «Задоволеність досягненнями у роботі» означає значимість результату діяльності. Дані за шкалою «Задоволеність взаємовідносинами 3 колегами» розкривають бажання працювати в колективі, задоволення від формальних та неформальних взаємовідносин із колегами. Шкала «Задоволеність взаємовідносинами з керівниитвом» вказує на ступінь прийняття працівниками стилю управління в організації та відношення до особистості керівника. За шкалою «Задоволеність професійним статусом» вказує на цінність престижу професії байдужість до професійного статусу чи потребу займати більш високу професійну сходинку. Шкала «Задоволеність змістом роботи порівняно із заробітком» вказує на важливість отримувати задоволення від процесу виконання функціональних обов'язків ніж розмір заробітної плати. За шкалою «Задоволеність умовами праці〉 свідчить про достатню задоволеність ергономічними та психологічними умовами праці Шкала «Професійна відповідальність» визначає міру усвідомлення та добровільного виконання особистістю своїх професійних обов'язків.

Спочатку розглянемо загальний рівень та рівні окремих складових задоволеності працею фахівців ДС3, що представлені в таблиці 1.

Отже, більшість фахівців виявляють помірний інтерес до професійної діяльності, середній та високий рівень задоволення досягненнями в роботі та умовами праці, взаємовідносинами 3 колегами і керівництвом. Задоволеність умовами праці $є$ важливим показником балансу «робота життя», який сприяє професійній самореалізації фахівців [12]. Низький рівень виявлено за шкалою «професійна відповідальність» $(34,3 \%)$ Також $27,4 \%$ фахівців виявляють незадоволення професійним статусом та $28,3 \%$ - заробітком. Отже, міра усвідомлення та реалізації свої професійних обов'язків, низький професійний статус та недостатня зарплата $є$ проблемним полем у рівні задоволеності професійною діяльністю фахівців.

Далі розглянемо особливості задоволеності працею фахівців ДСЗ за статтю, що представлені в таблиці 2.

Як бачимо з таблиці, у рівні задоволеності працею між жінками та чоловіками, що працюють в

Таблиця 1

Загальний рівень та рівні окремих складових задоволеності працею фахівців ДСЗ (у \% від загальної кількості опитаних)

\begin{tabular}{|l|c|c|c|}
\hline \multicolumn{1}{|c|}{ Шкали } & Низький рівень & Середній рівень & Високий рівень \\
\hline Інтерес до роботи & 5,3 & 87,4 & 7,2 \\
\hline Задоволеність досягненнями у роботі & 2,2 & 45,6 & 52,2 \\
\hline Задоволеність взасмовідносинами 3 колегами & 1,6 & 18,6 & 79,9 \\
\hline Задоволеність взаємовідносинами 3 керівництвом & 11,6 & 42,1 & 46,2 \\
\hline Задоволеність професійним статусом & 27,4 & 62,9 & 9,7 \\
\hline Задоволеність змістом роботи порівняно із заробітком & 28,3 & 58,8 & 12,9 \\
\hline Задоволеність умовами праці & 1,9 & 28,9 & 69,2 \\
\hline Професійна відповідальність & 34,3 & 42,5 & 23,3 \\
\hline Загальна задоволеність працею & 8,5 & 62,6 & 28,9 \\
\hline
\end{tabular}


Таблиця 2

Особливості загальної задоволеності працею фахівців ДСЗ

та її окремих складових за статтю (у стенах)

\begin{tabular}{|l|c|c|}
\hline \multicolumn{1}{|c|}{ Шкали } & жінки & чоловіки \\
\hline Інтерес до роботи & 3,60 & 3,47 \\
\hline Задоволеність досягненнями у роботі & 3,38 & 3,32 \\
\hline Задоволеність взаємовідносинами з колегами & 5,14 & 5,32 \\
\hline Задоволеність взаємовідносинами з керівництвом & 4,24 & 4,26 \\
\hline Задоволеність професійним статусом & 2,06 & 1,95 \\
\hline Задоволеність змістом роботи порівняно із заробітком & 2,09 & 2,26 \\
\hline Задоволеність умовами праці & 3,57 & 3,63 \\
\hline Професійна відповідальність & 0,88 & 1,00 \\
\hline Загальна задоволеність працею & 24,16 & 24,42 \\
\hline
\end{tabular}

Вікові особливості загальної задоволеності працею фахівців ДСЗ

Таблиця 3 та ії окремих складових (у стенах)

\begin{tabular}{|l|c|c|c|c|c|}
\hline \multicolumn{1}{|c|}{ Шкали } & до 25 років & $\begin{array}{c}\text { від 26 до } \\
\mathbf{3 5} \text { років }\end{array}$ & $\begin{array}{c}\text { від 36 до } \\
\mathbf{4 5} \text { років }\end{array}$ & $\begin{array}{c}\text { від 46 до } \\
\mathbf{5 5} \text { років }\end{array}$ & $\begin{array}{c}\text { старше } \\
\mathbf{5 5} \text { років }\end{array}$ \\
\hline Інтерес до роботи & 3,82 & 3,67 & 3,52 & 3,58 & 3,58 \\
\hline Задоволеність досягненнями у роботі & 3,45 & 3,45 & 3,31 & 3,42 & 3,30 \\
\hline Задоволеність взаємовідносинами з колегами & 5,45 & 5,07 & 5,09 & 5,22 & 5,23 \\
\hline $\begin{array}{l}\text { Задоволеність взаємовідносинами } \\
\text { 3 керівництвом }\end{array}$ & 4,45 & 4,43 & 4,09 & 4,46 & 3,84 \\
\hline Задоволеність професійним статусом & 1,82 & 1,82 & 2,22 & 2,10 & 2,07 \\
\hline $\begin{array}{l}\text { Задоволеність змістом роботи порівняно } \\
\text { із заробітком }\end{array}$ & 1,36 & 2,01 & 2,16 & 2,23 & 2,05 \\
\hline Задоволеність умовами праці & 3,82 & 3,62 & 3,52 & 3,60 & 3,51 \\
\hline Професійна відповідальність & $1,00^{*}$ & $0,98^{*}$ & $0,70^{*}$ & $1,04^{*}$ & $0,88^{*}$ \\
\hline Загальна задоволеністьь працею & 24,36 & 24,34 & 23,82 & 24,69 & 23,74 \\
\hline
\end{tabular}

* - $(\mathrm{p}<0,05)$

службі зайнятості, суттєвих відмінностей не виявлено. Отже, дані про відсутність суттєвих відмінностей у різних параметрах професійної самореалізації, які були представлені в наших попередніх дослідженнях [10], ще раз підтверджені.

Вікові особливості загальної задоволеності працею фахівців ДС3 та іiі складових наведено в таблиці 3.

За допомогою дисперсійного аналізу (ANOVA) встановлено, що існує позитивний статистично значущиий зв'язок $(\mathrm{p}<0,05)$ між таким чинником як вік фахівців та показником «професійна відnовідальність». Це вказує на те, що найвищий рівень професійної відповідальності притаманний фахівцям вікової категорії від 46 до 55 років. Також зазначимо, що фахівців віком до 25 років виявляють більший інтерес до діяльності, більш задоволені взаєминами з колегами, досягненнями в роботі та умовами праці, проте найменш задоволені заробітком та професійним статусом, що може бути обумовлено відносно невеликим досвідом роботи. За іншими показниками суттєвої різниці між віковими групами фахівців не виявлено.
Особливості загальної задоволеності працею фахівців ДС3 та їі складових в залежності від стажу роботи в ДСЗ представлено в таблиці 4.

Отже, найбільш задоволені досягненнями у роботі, умовами праці, взаємовідносинами 3 керівництвом і колегами та мають найвищий рівень професійної відповідальності - фахівці, що працюють в ДС3 від 5 до 10 років, хоча різниця 3 іншими фахівцями не суттєва. Також зазначимо, що за допомогою дисперсійного аналізу (ANOVA) встановлено існування позитивного статистично значущзого зв'язку $(\mathrm{p}<0,05)$ між інтересом до роботи та стажем роботи в ДСЗ. Це вказує на те, що найвищий рівень інтересу притаманний фахівцям, які не знають специфіки професійної діяльності та із задоволенням пізнають іiі.

Далі розглянемо особливості загальної задоволеності працею фахівців ДСЗ та їі складових в залежності від специфіки професійної діяльності (табл. 5).

Зауважимо, що статистично значущої різниці у загальному рівні та рівні окремих складових задоволеності працею між групами фахівців, що від- 
Таблиця 4

Особливості загальної задоволеності працею фахівців ДСЗ та її окремих складових в залежності від стажу роботи в ДСЗ (у стенах)

\begin{tabular}{|l|c|c|c|c|c|}
\multicolumn{1}{|c|}{ Шкали } & до 1 року & $\begin{array}{c}\text { від 1 до } \\
\mathbf{3} \text { років }\end{array}$ & $\begin{array}{c}\text { від 3 до } \\
\mathbf{5} \text { років }\end{array}$ & $\begin{array}{c}\text { від 5 до } \\
\mathbf{1 0} \text { років }\end{array}$ & $\begin{array}{c}\text { більше } \\
\mathbf{1 0} \text { років }\end{array}$ \\
\hline Інтерес до роботи & $3,91^{*}$ & $3,57^{*}$ & $3,67^{*}$ & $3,48^{*}$ & $3,53^{*}$ \\
\hline Задоволеність досягненнями у роботі & 3,44 & 3,24 & 3,28 & 3,55 & 3,39 \\
\hline $\begin{array}{l}\text { Задоволеність взаємовідносинами } \\
\text { 3 колегами }\end{array}$ & 5,21 & 4,94 & 4,96 & 5,38 & 5,20 \\
\hline $\begin{array}{l}\text { Задоволеність взаємовідносинами } \\
\text { 3 керівництвом }\end{array}$ & 4,47 & 4,16 & 4,26 & 4,65 & 4,11 \\
\hline Задоволеність професійним статусом & 1,85 & 1,86 & 2,00 & 2,14 & 2,15 \\
\hline $\begin{array}{l}\text { Задоволеність змістом роботи порівняно } \\
\text { із заробітком }\end{array}$ & 2,12 & 2,20 & 2,04 & 1,85 & 2,14 \\
\hline Задоволеність умовами праці & 3,50 & 3,53 & 3,41 & 3,65 & 3,64 \\
\hline Професійна відповідальність & 0,88 & 0,82 & 0,91 & 1,05 & 0,87 \\
\hline Загальна задоволеність працею & 24,79 & 23,59 & 23,63 & 24,93 & 24,19 \\
\hline
\end{tabular}

$*-(\mathrm{p}<0,05)$

Таблиця 5

Особливості загальної задоволеності працею фахівців ДСЗ та її окремих складових в залежності від специфіки професійної діяльності (у стенах)

\begin{tabular}{|l|c|c|c|}
\hline \multicolumn{1}{|c|}{ Шкали } & $\begin{array}{c}\text { надання послуг } \\
\text { безробітним }\end{array}$ & $\begin{array}{c}\text { надання послуг } \\
\text { роботодавцям }\end{array}$ & $\begin{array}{c}\text { адміністративно- } \\
\text { управлінська діяльність }\end{array}$ \\
\hline Інтерес до роботи & 3,57 & 3,68 & 3,55 \\
\hline $\begin{array}{l}\text { Задоволеність: } \\
\text { - досягненнями у роботі }\end{array}$ & 3,39 & 3,26 & 3,45 \\
\hline - взаємовідносинами 3 колегами & 5,15 & 5,19 & 5,10 \\
\hline - взаємовідносинами 3 керівництвом & 4,26 & 4,04 & 2,42 \\
\hline - професійним статусом & 1,99 & 2,12 & 2,08 \\
\hline - змістом роботи порівняно із заробітком & 2,10 & 2,09 & 3,66 \\
\hline - умовами праці & 3,55 & 3,56 & 0,94 \\
\hline Професійна відповідальність & 0,87 & 0,90 & 24,61 \\
\hline Загальна задоволеність працею & 24,10 & 23,99 & \\
\hline
\end{tabular}

різняються за специфікою професійної діяльності не виявлено. Таким чином, можна стверджувати, що незначні відмінності у показниках задоволеності працею фахівців лише опосередковано пов’язані із спеціалізацією фахівців ДСЗ.

Висновки. Рівень задоволеності професійною діяльність фахівців ДСЗ в цілому знаходиться на середньому рівні. Найбільше фахівці ДС3 задоволені взаємовідносинами 3 колегами та умовами праці, проте проблемними є параметри професійної відповідальністі, професійного статусу та змісту роботи порівняно із заробітком. Виявлені особливості задоволеності пра- цею у фахівців за статтю, віком, стажем роботи в ДС3 та специфікою професійної діяльності. Основні відмінності стосуються вікових груп фахівців, а, отже, рівнів особистісної зрілості (з якою пов' язана професійна відповідальність), стажу роботи. В цілому, результати цього етапу дослідження засвідчили наявність ряду проблем у рівні задоволеності професійною діяльністю фахівців служби зайнятості, що вказують на необхідність впровадження та застосування технологій розвитку їх професійної самореалізації загалом та підвищення рівня задоволеності професійною діяльністю зокрема.

\section{ЛІТЕРАТУРА}

1. Вірна Ж., Мудрик А. Особистісна вимогливість як чинник ефективної професійної реалізації державного службовця. Психологія і суспільство. 2013. № 3. С. 99-109.

2. Карамушка Л.М. Ткалич М.Г. Самоактуалізація менеджерів у професійно-управлінській діяльності (на матеріалі діяльності комерційних організацій): Монографія. Запоріжжя.: «Просвіта», 2009. $262 \mathrm{c}$. 
3. Кокун О.М. Психологія професійного становлення сучасного фахівця: монографія. К. : ДП «Інформ.-аналіт. Агенство», 2012. 200 с.

4. Компетентнісний підхід як інструмент розвитку кадрового потенціалу державної служби зайнятості України : матеріали круглого столу. К. : ІПК ДСЗУ, 2012. 33 с.

5. Коростылева Л.А. Психология самореализации личности: затруднения в профессиональной сфере. СПб. : Речь, 2005. 222 с.

6. Малімон Л.Я. Задоволеність працею як інтегративний показник професійного благополуччя працівника організації. Психічне здоров'я публічних службовців : матеріали дослідження. Луцьк : Волиньполіграф, 2018. С. 17-30.

7. Ортікова Н.В. Проблематика побудови моделі кар'єрного зростання фахівців державної служби зайнятості : теоретичний аспект. Проблеми сучасної психологї. 2019. № 2. С. 85-90.

8. Профілювання та кейс-менеджмент в сфері зайнятості населення : метод. посібник / Волгіна О., Гусак Н. та ін. : за заг. ред. О. Іванова, О. Волгіна; ПРООН в Україні, Проект «Підтримка реформи соиіального сектору в Україні». Київ : Ваіте, 2017. 72 с.

9. Психологічні технології самодетермінації розвитку особистості: монографія / Л.З. Сердюк, І.В. Данилюк, В.В. Турбан, О.І. Пенькова, Н.Д. Володарська та ін. ; за ред. Л.З. Сердюк. К. : Інститут психології імені Г.С. Костюка НАПН України, 2018. 192 с.

10. Ткалич М.Г. Психологія гендерної взаємодії персоналу організацій : [монографія]. Київ-Запоріжжя: ЗНУ, 2015. $315 \mathrm{c}$.

11. Ткалич М.Г., Дубяга Я.І. Психолого-організаційні технології розвитку професійної самореалізації фахівців ДСЗУ. Психологія особистості на сучасному ринку праці: монографія. Херсон: ОЛДІ-ПЛЮС, 2020. С. 237-244

12. Tkalych, M., Snyadanko, I., Guba, N., Zhelezniakova, Yu. (2020) Social and psychological support for personnel in organizations: work-life balance programmes. Journal of Intellectual Disability - Diagnosis and Treatment, Vol. 8, \# 2, pp. 159-166

\section{REFERENCES}

1. Virna Zh., Mudryk A. (2013) Osobystisna vymoglyvist' jak chynnyk efektyvnoi' profesijnoi' realizacii' derzhavnogo sluzhbovcja [Personal demands as a factor of effective professional realization of a civil servant]. Psyhologija i suspil'stvo. № 3. S. 99-109. [in Ukrainian]

2. Karamushka L.M. Tkalych M.G. (2009) Samoaktualizacija menedzheriv u profesijno-upravlins'kij dijal'nosti [Self-actualization of managers in professional and managerial activity]: Monografija. Zaporizhzhja.: «Prosvita». 262 s. [in Ukrainian]

3. Kokun O.M. (2012) Psyhologija profesijnogo stanovlennja suchasnogo fahivcja [Psychology of professional development of a modern specialist]: monografija. K. : DP «Inform.-analit. Agenstvo». $200 \mathrm{~s}$. [in Ukrainian]

4. Kompetentnisnyj pidhid jak instrument rozvytku kadrovogo potencialu derzhavnoi' sluzhby zajnjatosti Ukrai'ny [Competence approach as a tool for developing the human resources potential of the state employment service of Ukraine:] : materialy kruglogo stolu. K. : IPK DSZU, 2012. 33 s. [in Ukrainian]

5. Korostyleva L.A. (2005) Psihologija samorealizacii lichnosti: zatrudnenija v professional'noj sfere. SPb. : Rech'. 222 s. [in Russian]

6. Malimon L. Ja. (2018) Zadovolenist' praceju jak integratyvnyj pokaznyk profesijnogo blagopoluchchja pracivnyka organizacii' [Job satisfaction as an integrative indicator of professional well-being of an employee of the organization]. Psyhichne zdorov'ja publichnyh sluzhbovciv : materialy doslidzhennja. Luc'k : Volyn'poligraf. S. 17-30. [in Ukrainian]

7. Ortikova N.V. (2019) Problematyka pobudovy modeli kar'jernogo zrostannja fahivciv derzhavnoi' sluzhby zajnjatosti : teoretychnyj aspekt [Problems of building a model of career growth of specialists of the state employment service: a theoretical aspect]. Problemy suchasnoi' psyhologii'. № 2. S. 85-90. [in Ukrainian]

8. Profiljuvannja ta kejs-menedzhment v sferi zajnjatosti naselennja : metod. Posibnyk [Profiling and case management in the field of employment] / Volgina O., Gusak N. ta in. : za zag. red. O. Ivanova, O. Volgina; PROON v Ukrai'ni, Proekt «Pidtrymka reformy social'nogo sektoru v Ukrai'ni». Kyi'v : Vaite, 2017. $72 \mathrm{~s}$. [in Ukrainian]

9. Psyhologichni tehnologii' samodeterminacii' rozvytku osobystosti [Psychological technologies of selfdetermination of personality development] : monografija / L. Z. Serdjuk, I. V. Danyljuk, V. V. Turban, O. I. Pen'kova, N. D. Volodars'ka ta in. ; za red. L. Z. Serdjuk. K. : Instytut psyhologii' imeni G.S. Kostjuka NAPN Ukrai'ny, 2018. 192 s. [in Ukrainian] 
10. Tkalych M.G. (2015) Psyhologija gendernoi' vzajemodii' personalu organizacij [Psychology of gender interaction of personnel of organizations]: [monografija]. Kyi'v-Zaporizhzhja: ZNU. 315 s. [in Ukrainian]

11. Tkalych M.G., Dubjaga Ja.I. (2020) Psyhologo-organizacijni tehnologii' rozvytku profesijnoi' samorealizacii' fahivciv DSZU [Psychological and organizational technologies for the development of professional self-realization of SESU specialists]. Psyhologija osobystosti na suchasnomu rynku praci: monografija. Herson: OLDI-PLJuS. S. 237-244

12. Tkalych, M., Snyadanko, I., Guba, N., Zhelezniakova, Yu. (2020) Social and psychological support for personnel in organizations: work-life balance programmes. Journal of Intellectual Disability - Diagnosis and Treatment, Vol. 8, \# 2, pp. 159-166 